\title{
Aplikasi Sistem Informasi Geografis Kos Di Palangka Raya Berbasis Android
}

\author{
Abertun Sagit Sahay $^{\mathrm{a}, 1,{ }^{*}}$, Agus Sehatman Saragih ${ }^{\mathrm{b}, 2}$, Sufridianson ${ }^{\mathrm{b}, 3}$ \\ a Jurusan Teknik Informatika FT UPR, Jl H. Timang Tunjung Nyaho \\ ${ }^{\mathrm{b}}$ Jurusan Teknik Informatika FT UPR, Jl H. Timang Tunjung Nyaho \\ 'Jurusan Teknik Informatika FT UPR, Jl H. Timang Tunjung Nyaho \\ 1'abetun@gmail.com; ${ }^{2}$ assaragih@gmail.com;
}

ARTICLE INFO

Keywords

geographic Information System home boarding

location

\begin{abstract}
Usage of Android Smartphone in home boarding information can give big benefit. If it is compared with searching of home boarding location manually, search with the application has some surplus, such as: a user can search through android smartphone everytime and everywhere, and also can see the detail of home boarding information. Search of home boarding in Palangka Raya city is still executed manuallys. For developing a geographic information system of home boarding search for Palangka Raya area that can find the nearest location, The Methodologhy used is Waterfall methodologhy that has 5 steps: (1) requirement: Actors those are administrator, home boarding owner and visitors. some of data are photo, latitude and longitude, and home boarding information. (2) Design System: design system in this research used UML(Unified Modeling Language). (3) Coding \& Testing: this step used Java Programming, Database MySQL and XAMPP and using Haversine Algorithm for home boarding searching. (4) Integration \& Testing, Testing of all system used Blackbox testing. (5) Operation and Maintanance, this step for seeing change that is needed for fungtionalization of development. According to developing of geographic information system of home boarding search. The conclusion are the user can know the nearest home boarding location from user's position with using radius feature that used haversine algorithm, the owner of home boarding manage directly with giving original information and the application also help the owner on home boarding marketing.
\end{abstract}

\section{Pendahuluan}

Palangka Raya adalah ibukota provinsi Kalimantan Tengah di mana banyak sekali orang pendatang dari berbagai macam daerah di provinsi Kalimantan Tengah maupun di luar Kalimantan Tengah yang datang ke Palangka Raya, tujuan mereka ke Palangka Raya beragam ada yang datang untuk sekolah/kuliah ada juga yang datang untuk mencari perkerjaan, karena banyaknya pendatang yang baru ke Palangka Raya sehingga banyak dari mereka tidak mempunyai tempat tinggal dan membutuhkan tempat tinggal sementara atau yang biasa di sebut dengan tempat kost. Kost di Palangka Raya ada banyak sekali dengan berbagai macam tipe dan kisaran harga, walaupun kost di Palangka Raya banyak tapi tidak semua orang tahu letak atau alamat kost dan kisaran harga yang pas sesuai keinginan mereka yang ingin mencari tempat kost. Berdasarkan permasalahan tersebut adalah bagaimana merancang dan membuat aplikasi sistem informasi geografis kost di Palangka Paya berbasis android ? 


\section{Metodologi Penelitian}

\subsection{Metode Pengumpulan Data}

1. Studi pustaka

Tahapan ini merupakan pengumpulan data dengan mengambil beberapa sumber pustaka sebagai referensi yang terkait dengan sistem informasi geografis dan ada hubungannya dengan data yang diperlukan agar dapat memecahkan masalah berdasarkan teori-teori yang ada.

2. Obsevasi

Tahapan ini merupakan pengumpulan data dengan melakukan peninjauan langsung ke objek penelitian yaitu tempat yang ada di palangka raya untuk akan diteliti sehingga akan mendapatkan data yang lebih aktual dari hasil penelitian yang dilakukan.

\subsection{Metode Pengembangan Perangkat Lunak}

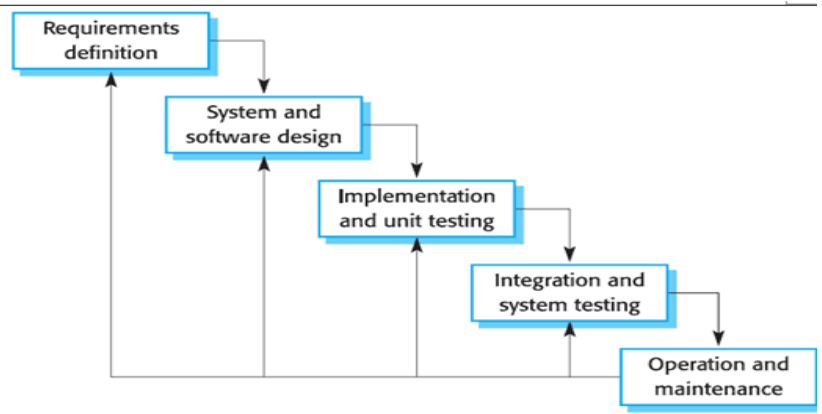

Gambar 1 Metodologi Pengembangan Perangkat Lunak

\section{Hasil dan Pembahasan}

\subsection{Perancangan}

Pada tahapan awal yaitu tahap analisis, dilakukan penggambaran proses bisnis seperti pada Gambar 2 berikut ini : 


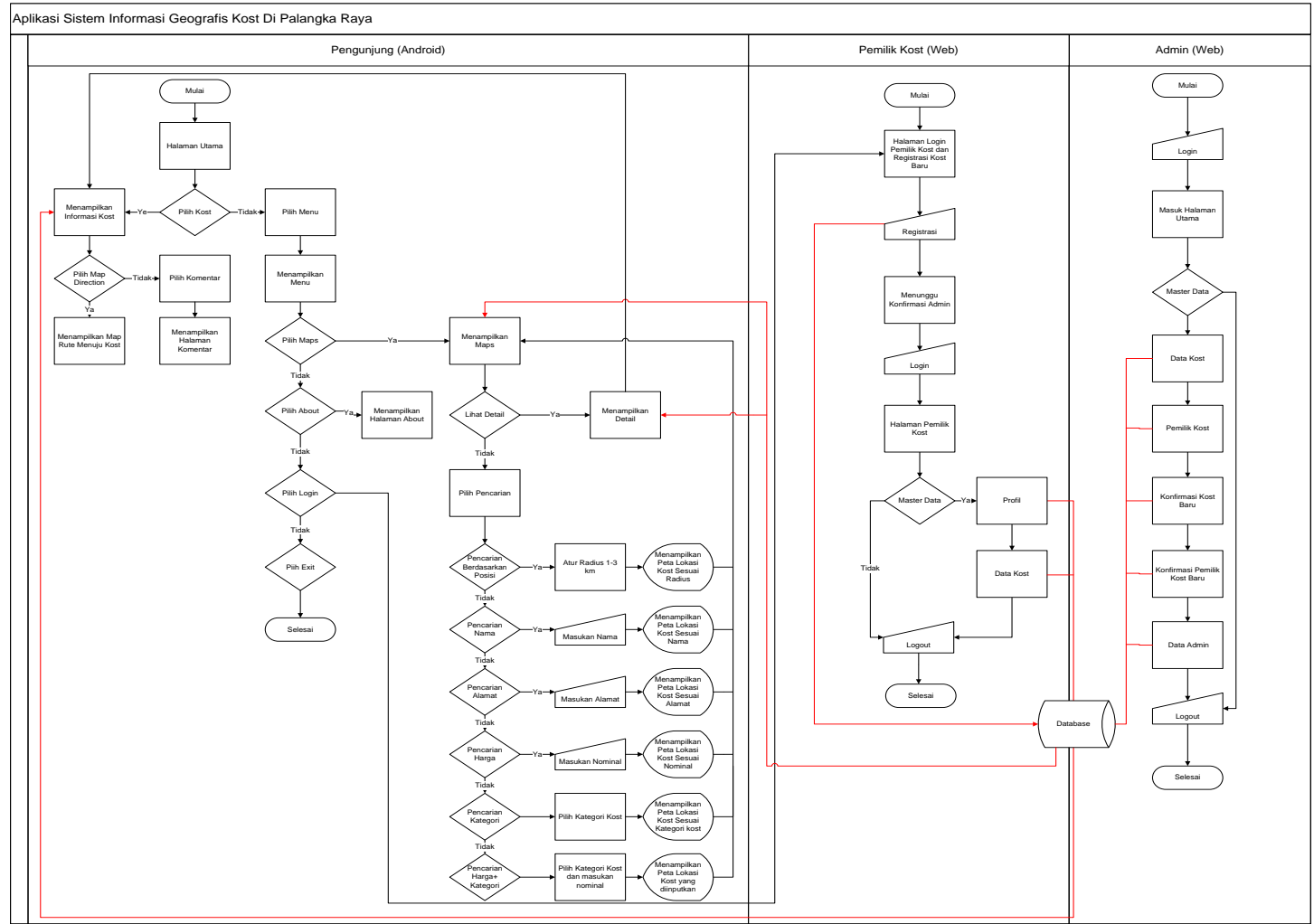

Gambar 2. Flowchart Sistem Baru

Dalam perancangan dan pembangunan sistem informasi ini, digunakan 2 alat perancangan UML dan DFD karena terdapat dua sisi pengguna, yaitu pengguna android yang perancangannya menggunaan usecase diagram seperti pada Gambar 3 dan class diagram yang ditunjukan Gambar 4.

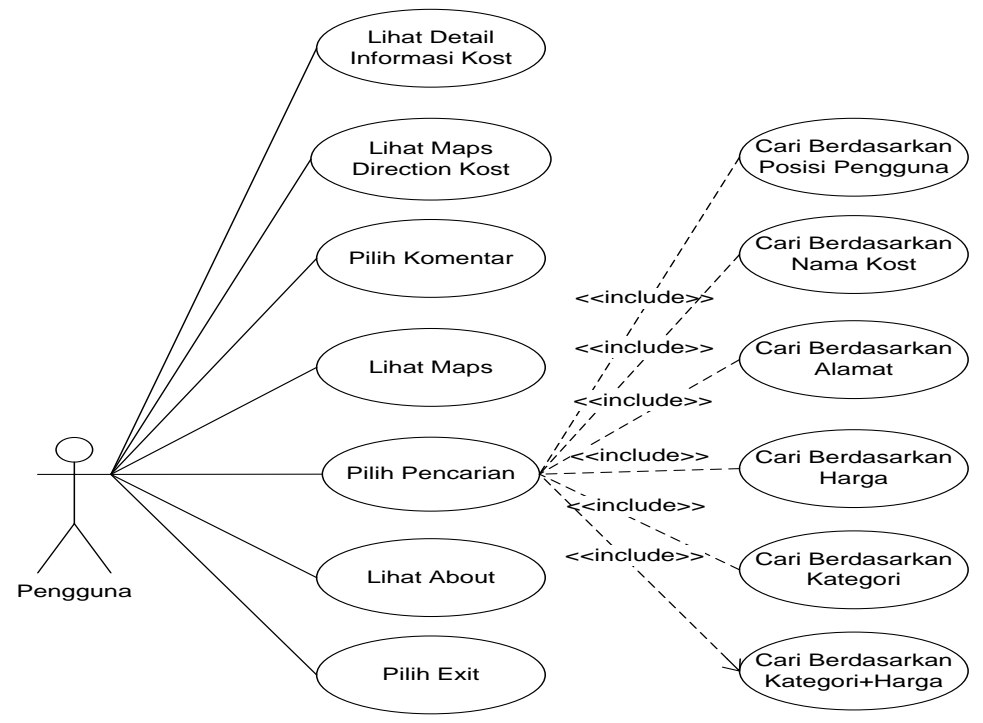

Gambar 3. Usecase Diagram Pengguna Android 

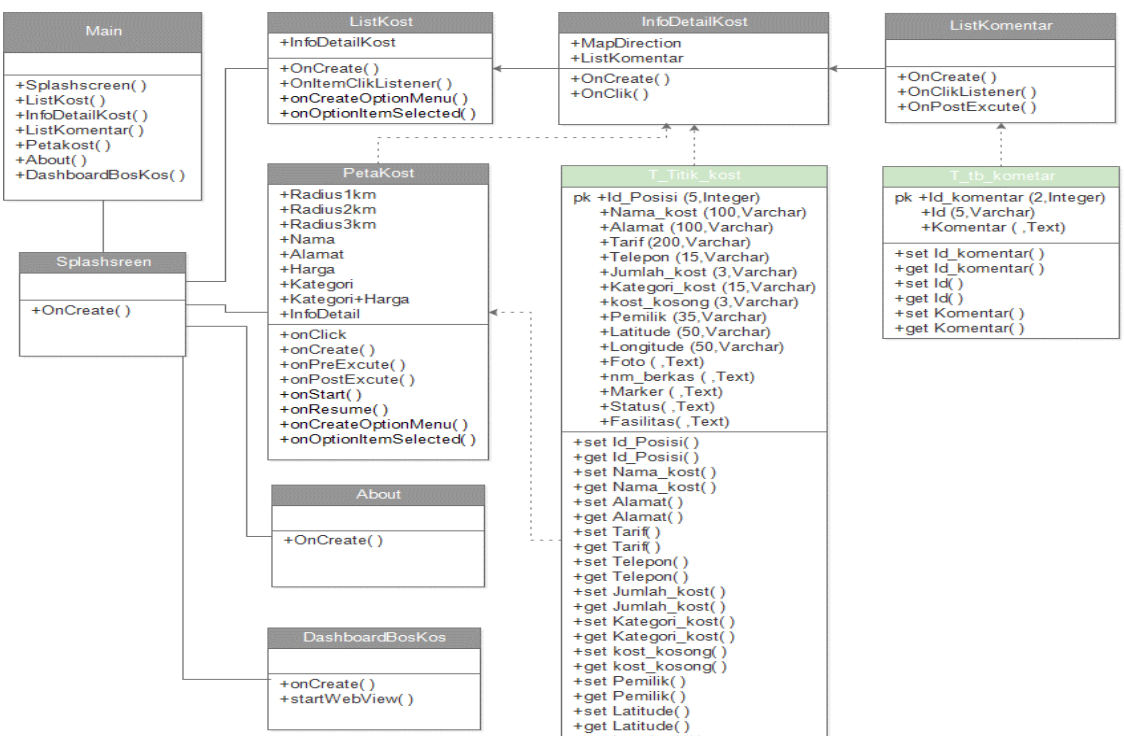

Gambar 4. Class Diagram

sementara di pengguna website yaitu admin, menggunakan DFD yaitu context diagram pada Gambar 5 dan DFD level 0 seperti pada Gambar 6.

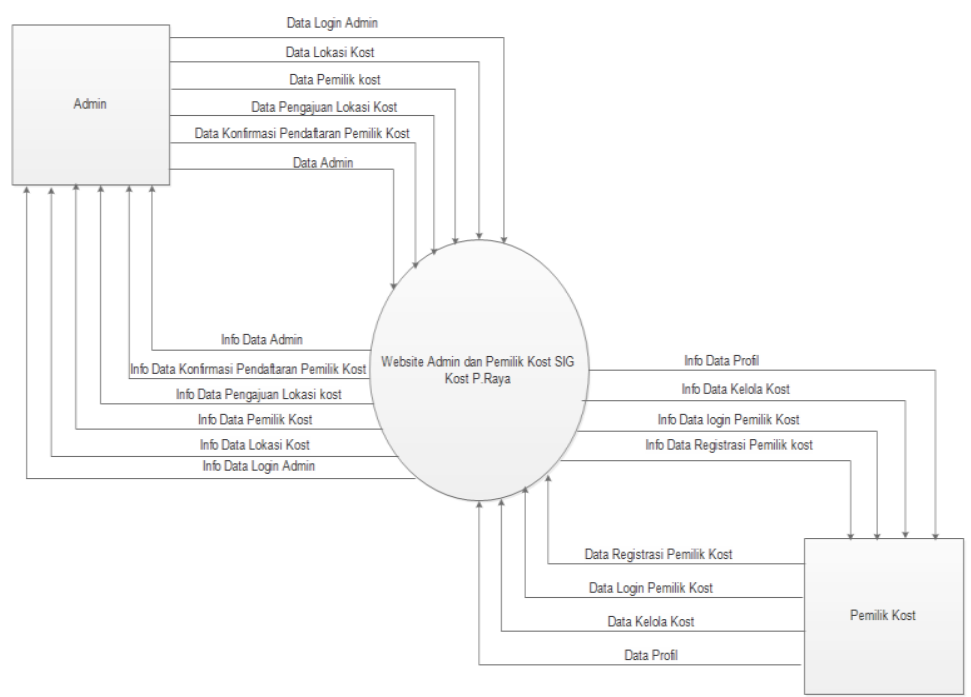

Gambar 5. Diagram Konteks 


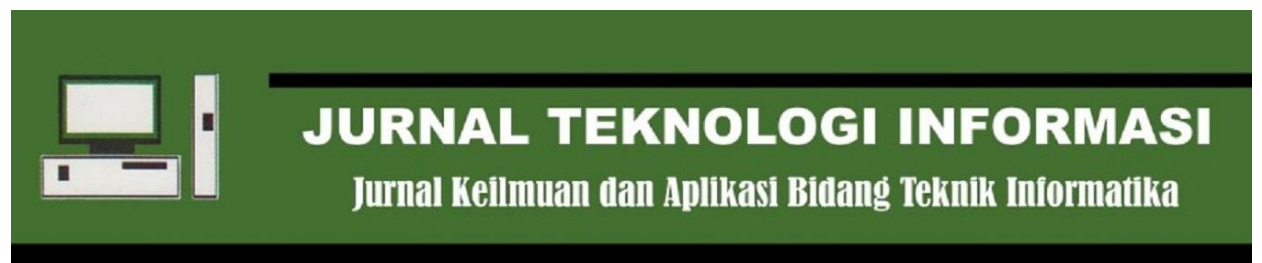

[E-ISSN 2656-0321]

[Vol 14 No 1]

[ Januari 2020]

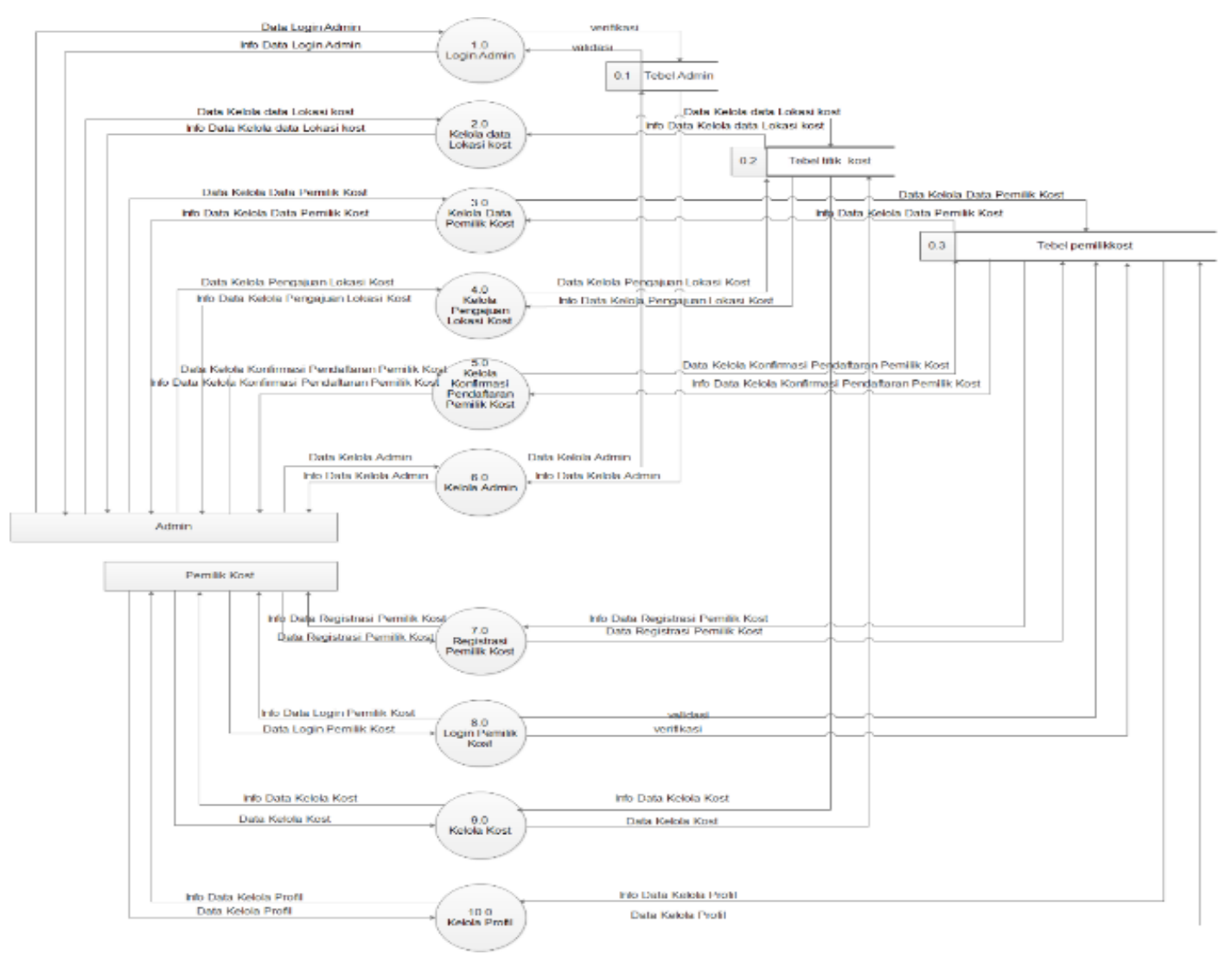

Gambar 6. DFD Level 0

\subsection{Hasil}

Seperti yang telah dijelaskan bahwa sistem yang dibangun terdiri dari dua sistem pertama berbasis web untuk sisi admin dan berbasis android untuk pengguna android.

Dari sisi admin, dalam pengelolaan sistem, admin harus login di halaman login seperti pada Gambar 7 berikut ini. 


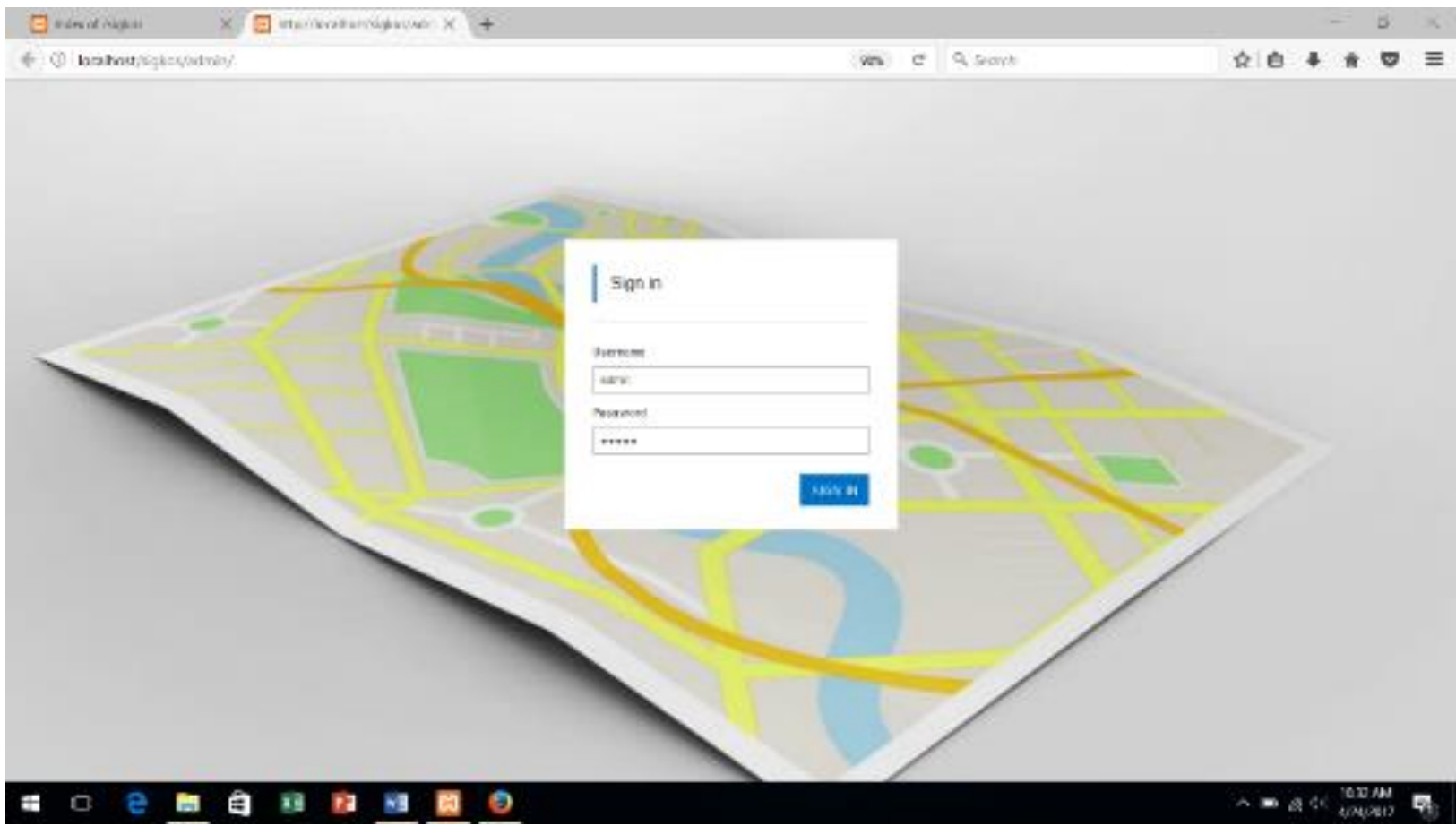

Gambar 7. Halaman Login Admin Kos

Setelah login, admin masuk ke halaman kelola sistem seperti pada Gambar 8 .

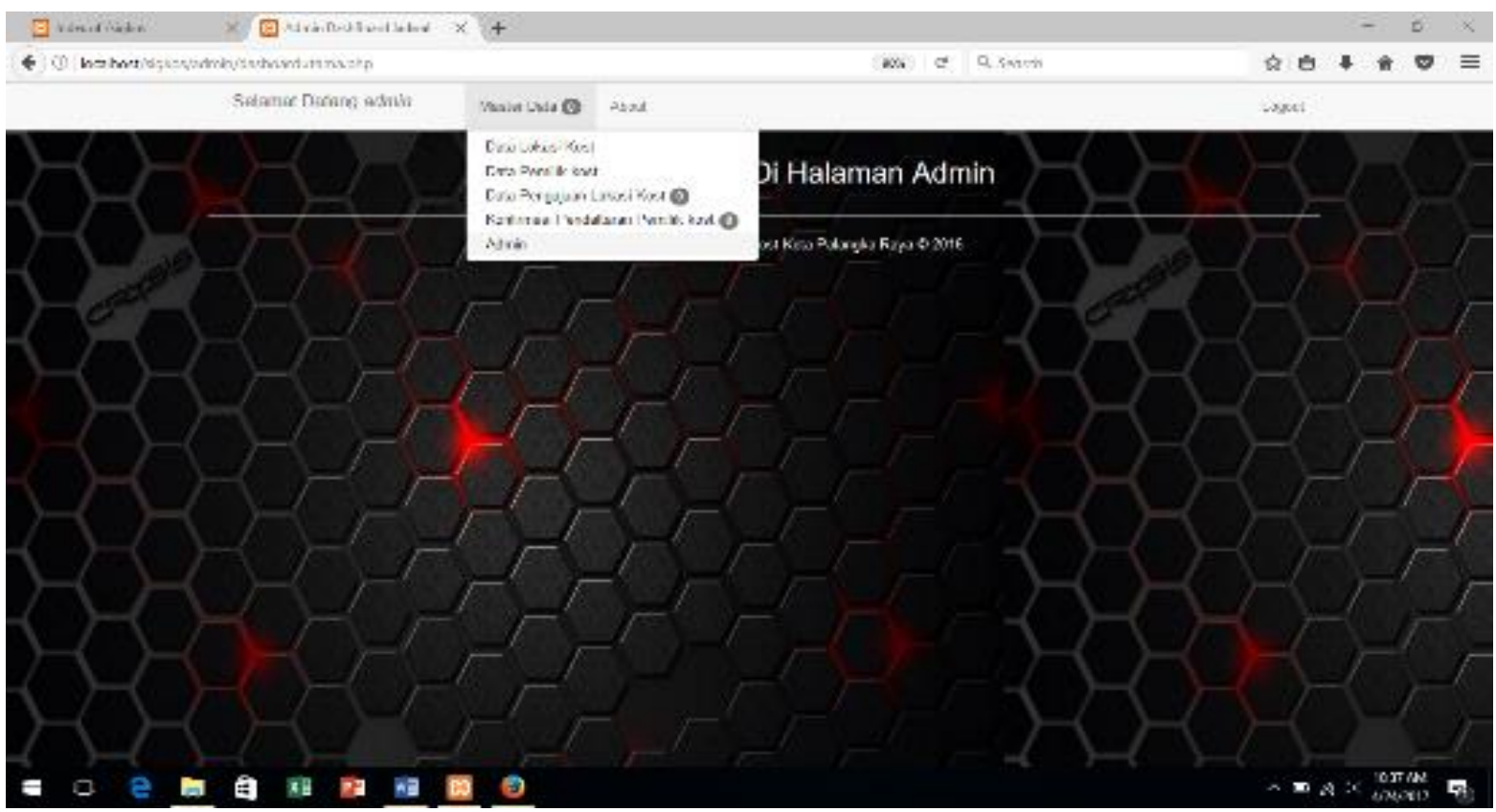

Gambar 8. Halaman Admin Kos 
Admin Kos adalah pemilik kos yang sudah mendaftar atau registrasi ke sistem yang diverifikasi oleh Admin Sistem. Sehingga pemilik kos mengelola halaman websitenya masing-masing. Halaman registrasi Admin kos dapat dilihat pada Gambar 9 di bawah ini :

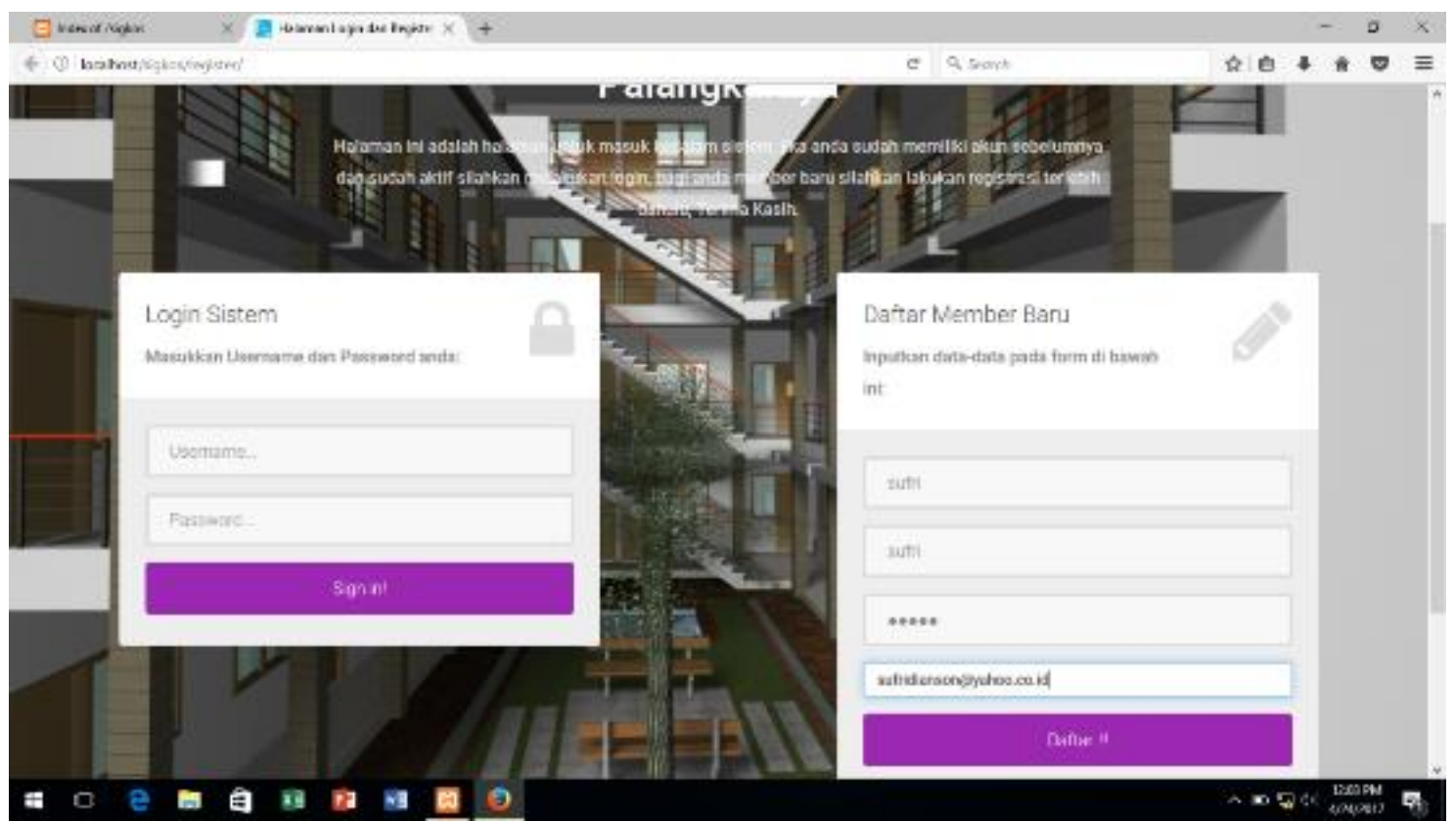

Gambar 9. Halaman Registrasi Pemilik Kos

Sementara dari sisi pengguna android, dapat melihat daftar kos yang telah teregistrasi dan melihat informasi detail tentang kos tersebut seperti pada Gambar 10 berikut ini :

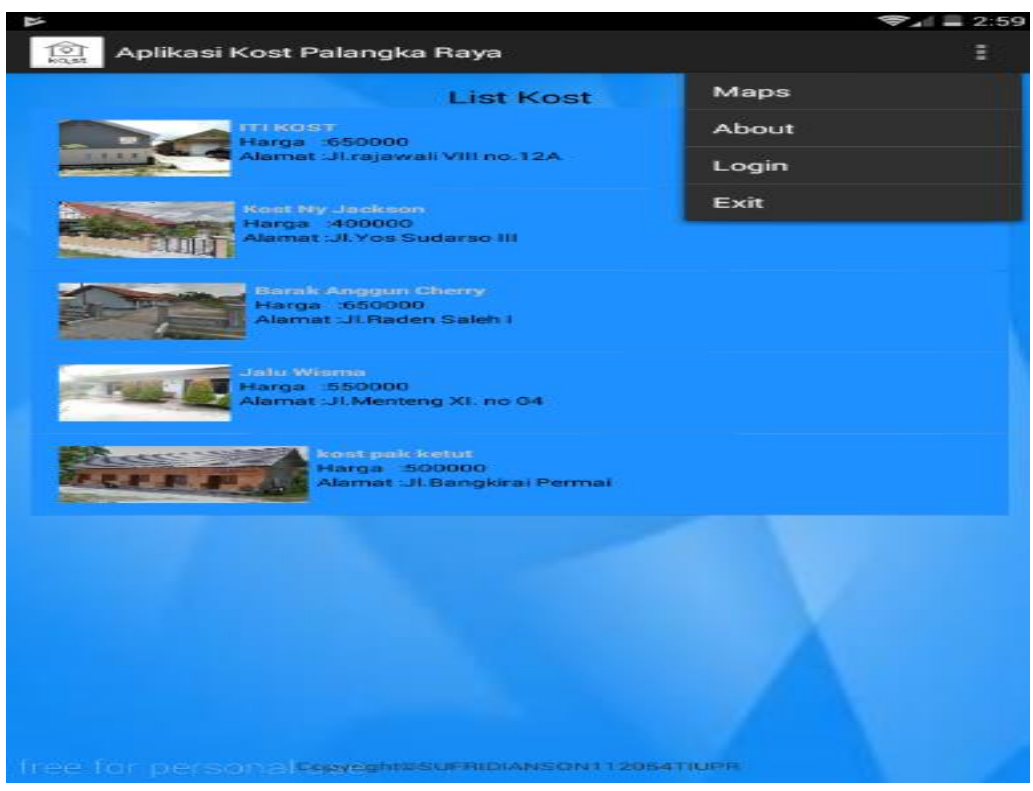

Gambar 10. Halamamn Utama Pengguna Android 


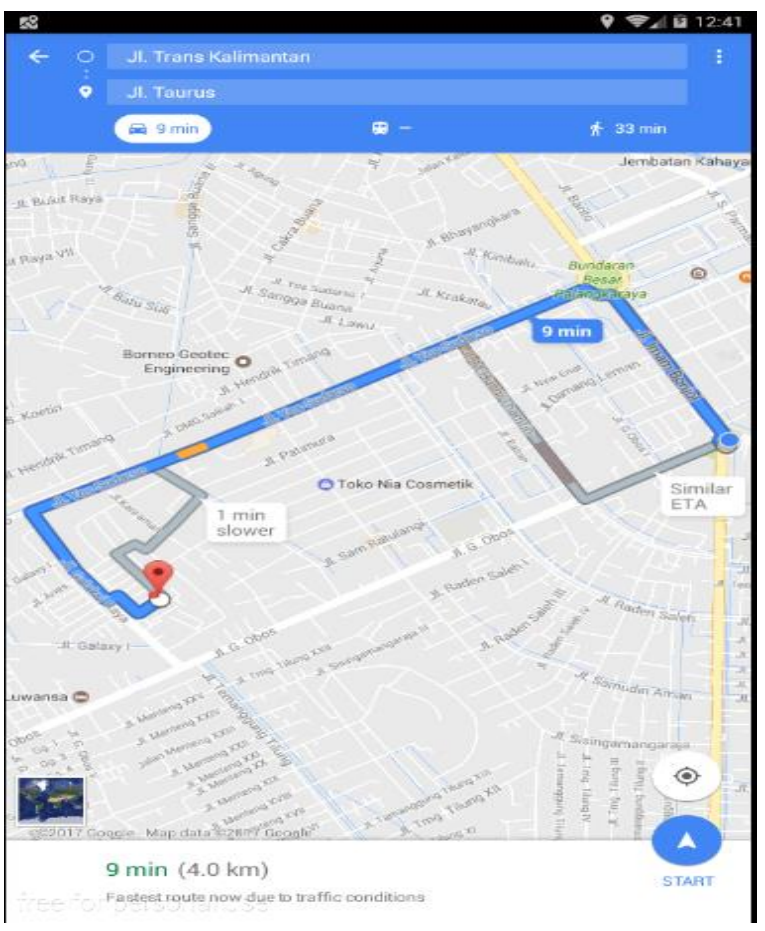

Gambar 11. Proses pencarian direction

Pada Gambar 11 di atas, merupakan prose pencarian lokasi kos yang ingin dituju. Sehingga proses ini membantu pengguna dalam mencari lokasi kos di area Palangka Raya.

Pada tahapan selanjutnya dilakukan proses pengujian sistem dimana pengujian sistem menggunakan blackbox testing. Hasil dari pengujian ini adalah sistem berjalan sesuai dengan yang dirancang dan tidak terdapat error program.

\section{Kesimpulan}

Dalam pembuatan sistem informasi geografis kos di Palangka Raya berbasis Android ini menggunakan metodologi Waterfall dimana dari tahapan analisis, penggunanya ada 3 (tiga) yaitu Admin Sistem, Admin Kos dan Pengguna Android. Admin Sistem mengelola sistem yang berbasis website dan admin kos mengelola informasi kos melalui website. Pada tahapan desain, desain database menggunakan class diagram. Sementara tahapan pengujian menggunakan blackbox testing.

\section{Daftar Pustaka}

[1] Abidin, H.Z., Penentuan Posisi dengan GPS dan Aplikasinya. Pradnya Paramita: Jakarta, 2007

[2] Kadir.Abdul, Pengenalan Sistem Informasi.Jakarta.Andi Offse K, 2002

[3] Nugroho.A. Pemrograman Java Menggunakan IDE Eclipse.Yogyakarta : Penerbit Andi, 2008

[4] Nugroho.A., Rekayasa Perangkat Lunak Menggunakan UML \& Java.Yogyakarta: Andi Offset, 2009

[5] Ladjamudin.Bahra. Analisis dan Desain Sistem Informasi.Yogyakarta.Graha Ilmu, 2005 